\title{
The conservation status of birds on the Cordillera de Colán, Peru
}

\author{
C. W. N. DAVIES, R. BARNES, S. H. M. BUTCHART, M. FERNANDEZ \\ and N.SEDDON
}

\begin{abstract}
Summary
In July and August 1994, we surveyed two areas in the south of the Cordillera de Colán, Amazonas department, Peru, above the north bank of the rio Utcubamba. We found a high rate of deforestation, with trees being felled for timber, forest being cleared for the cultivation of cash crops, and elfin forest being burned for pasture. Most of the forest on the mountain range may have been cleared in 10 years. We recorded a number of important bird species, highlighting the significance of the area for the conservation of biodiversity; globally threatened birds included Peruvian Pigeon Columba oenops, Military Macaw Ara militaris and Royal Sunangel Heliangelus regalis. Elfin forest is under particular threat in the area, but probably still holds species such as Long-whiskered Owlet Xenoglaux loweryi. We recommend that a protected area containing areas of cloud-forest and elfin forest be established on the Cordillera de Colán.
\end{abstract}

\section{Introduction}

The Andean mountain chain is one of the most biologically diverse areas of the world. ICBP (1992) identified 23 Endemic Bird Areas (EBAs) in the Andes, reflecting a pattern of endemism corresponding well with data on other animal and plant groups (ICBP 1992). The tropical Andes must be considered a high priority for conservation, because of their high biodiversity and severe environmental degradation. In Peru, there are several large effectively protected areas of wet montane forest in the south and centre the country, the northernmost being Río Abiseo National Park centred at $8^{\circ} \mathrm{S}$, but the only protected area of wet montane forest in the north is the Alto Mayo Protection Forest which aims at watershed rather than biological resource conservation (INRENA 1995).

The biogeography of the eastern Andes of Peru is extremely complex. Fitzpatrick et al. (1979) suggested that the island-like configurations of isolated mountain ridges may have provided conditions of reduced competition, within which relict populations persisted and differentiated. Fjeldsă (1992) noted, however, that the ranges of many local species straddle what have traditionally been considered as major biogeographic boundaries, such as the río Marañon, and concluded that areas of long-term habitat stability may concentrate relict groups.

The Cordillera de Colán (Figure 1), in Amazonas department, Peru, is an important centre of endemism, rich in relict taxa (Fjeldså (1992). A semi-isolated mountain range to the east of the Andean chain, it is delimited by the río Marañon to the west, the río Utcubamba to the south, and the río Chiriaco to the east. Fjeldså (1992) identified it as a climatically stable area, with a correspondingly high concentration of relict groups, which may have become 


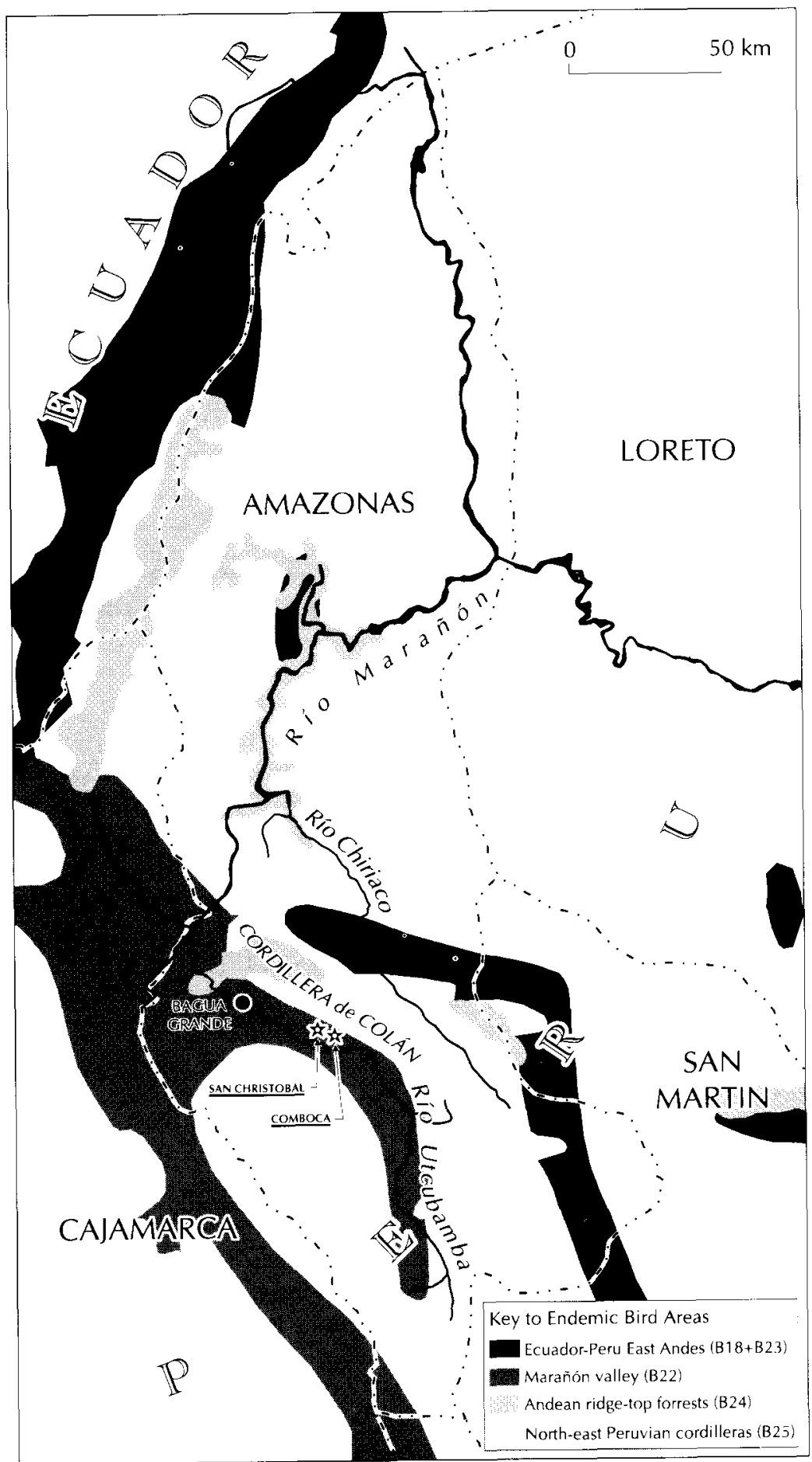

Figure 1. Map of Endemic Bird Areas represented on the Cordillera de Colán. 
extinct in areas less consistently wet over recent geological time. BirdLife International divides the Cordillera de Colán between four EBAs (Stattersfield et al. 1995): the north-east Peruvian Cordilleras, extending along the eastern side of the Andes from $5^{\circ} \mathrm{S}$ to $10^{\circ} \mathrm{S}$; the Andean Ridgetop Forests, covering low-altitude ridgetop elfin forest in southern Ecuador and northern Peru; the Maranón Valley, covering dry forest, mostly at low altitudes, in the Marañon watershed in Amazonas and Cajamarca departments; and the Ecuador-Peru East Andes, covering wet forests of foothills and lower mountain slopes of the East Andes in south-eastern Ecuador and northern Peru. At the intersection of at least four centres of endemism, the Cordillera de Colán is of immense importance for the conservation of biodiversity.

The distribution of habitat types on the mountain range itself is as complex as the biogeography. The eastern slope of the range tends to be wetter than the western (INRENA 1976), because the prevailing winds in the area are moisture-laden easterlies from the Amazon basin. The highest altitudes, to $3779 \mathrm{~m}$, in the north-west of the Cordillera de Colán, are capped by páramo ( $\mathrm{T}$. S. Schulenberg in litt. 1994). The southern and eastern parts of the Cordillera de Colán, entirely below $3000 \mathrm{~m}$, are covered by montane forest in even their highest reaches.

Elfin forest is probably the habitat type on the mountain range of greatest conservation importance. Particularly unusual is the presence of elfin forest down to $1500 \mathrm{~m}$ on the western slope of the Cordillera de Colán. This low elfin forest is almost certainly the result of a strong Massenerhebung effect (Richards 1952), by which isolated mountain ranges and parts of mountain ranges rising abruptly from lowland areas have vegetational and climatic zones at lower altitudes. High rainfall is another explanation for the unusually low elfin forest. If this were the major factor, however, elfin forest would extend lower on the wetter eastern slope of the Cordillera de Colán; the lowest known elfin forest is found on the western slopes.

The fauna of the Cordillera de Colán is still poorly known; there have been only two previous biological expeditions (Mittermeier et al. 1975; T. S. Schulenberg in litt. 1994). This paper reviews the current conservation status of birds on the Cordillera de Colán, focusing on our 1994 fieldwork in the southern part of the mountain range. We will recommend a conservation policy for the Cordillera de Colán and its avifauna.

\section{Methods}

General field observation was our predominant means of data collection. We have opted for lucidity and present raw data: the number of individuals of each bird species recorded at each site. Birds recorded include both birds heard and seen. We carried out mist-netting using $108 \mathrm{~m}$ of 4 -panel mist-net at five locations.

\section{Sites surveyed in 1994}

We visited the Cordillera de Colán between 13 July and 31 August and carried out fieldwork in two areas on the north bank of the rio Utcubamba, east of 
Table 1. Fieldwork sites

\begin{tabular}{|c|c|c|c|c|c|c|}
\hline \multirow[t]{2}{*}{ Site } & \multirow[t]{2}{*}{ Dates (1994) } & \multicolumn{2}{|c|}{$\begin{array}{l}\text { Field- } \\
\text { hours }\end{array}$} & \multicolumn{2}{|c|}{$\begin{array}{l}\text { Mist-net } \\
\text { hours }\end{array}$} & \multirow[t]{2}{*}{$\begin{array}{l}\text { Altitudinal } \\
\text { range (m) }\end{array}$} \\
\hline & & $\mathrm{d}$ & $\mathrm{n}$ & $\mathrm{d}$ & $\mathrm{n}$ & \\
\hline IA. Comboca Village & 13 July-15 July & $\mathrm{n} / \mathrm{a}$ & $\mathrm{n} / \mathrm{a}$ & - & - & $750-1500$ \\
\hline IB. Tesoro & 15 July-22 July & 219 & 15 & 129 & - & $1500-2150$ \\
\hline${ }_{1} \mathrm{C}$. Cabañaquinta & 22 July-6 August & 286 & 8 & 319 & 155 & $2150-2650$ \\
\hline 2A. San Cristobal Village & 12 August-16 August & $\mathrm{n} / \mathrm{a}$ & $\mathrm{n} / \mathrm{a}$ & - & - & $900-1100$ \\
\hline 2B. Europa Cloud-forest & 15 August-31 August & 149 & 3 & - & - & $1650-1850$ \\
\hline 2C. Europa Elfin forest & 15 August-31 August & 97 & 14 & 334 & 54 & $1650-1950$ \\
\hline
\end{tabular}

"A "field-hour" is one hour of field observation carried out by a single person or group of people working together.

"A "mist-net hour" is the operation of a single $18 \mathrm{~m}$ mist-net for one hour.

d, diurnal; n, nocturnal.

Bagua Grande; both were on the western slope of the south-eastern extension of the Cordillera de Colán. Study Area 1, in the rio Comboca catchment, is $30 \mathrm{~km}$ east of Bagua Grande; Study Area 2, in the río Cristobal catchment, is about $20 \mathrm{~km}$ east of Bagua Grande (Figure 1). Forest classification follows INRENA (1976), an ecological map of Amazonas department drawn using the Holdridge system of forest classification (Holdridge et al. 1971), based on annual rainfall and temperature.

Site 1A: Comboca Village The only access to the village of Comboca is across the río Utcubamba at the village of Cerezo, which lies at $700 \mathrm{~m}$ about $30 \mathrm{~km}$ east of Bagua Grande, at $5^{\circ} 54^{\prime} \mathrm{S} 78^{\circ} \mathrm{o} 6^{\prime} \mathrm{W}$. A single mule trail leads up from the river to Comboca, a small village of approximately 100 people located at an altitude of $1250 \mathrm{~m}$ at $5^{\circ} 27^{\prime} \mathrm{S} 78^{\circ} \mathrm{O} 4^{\prime} \mathrm{W}$. Villagers cultivate coffee, maize, sugar cane and bananas but some patches of intact forest remain around the settlement. We did not conduct fieldwork at this site but made informal observations in dry premontane forest and scrub at $700-800 \mathrm{~m}$, and in humid premontane forest at $800-1500 \mathrm{~m}$, while birdwatching around Comboca village and along the trail to Cerezo.

Site $1 B$ : Tesoro en la Selva Tesoro en la Selva is a single house at $1890 \mathrm{~m}, 5^{\circ} 49^{\prime} \mathrm{S}$ $78^{\circ} \mathrm{Oz} ' \mathrm{~W}$. An area of approximately to hectares has been cleared for cultivation of tuber crops, sugar cane, coffee and bananas. The surrounding forest has a high concentration of fruiting and flowering trees, including Nicotiana, Salpichroa, Solanum and Cinchona, and supports correspondingly high concentrations of frugivores. Villagers from Comboca ascend daily with mules to cut mahogany Cedrella at $1500-2150 \mathrm{~m}$. The use of chainsaws means that logging can proceed extremely quickly; the rate of logging appeared to be limited only by the rate of timber transport down to the río Utcubamba by mule.

We carried out fieldwork in humid lower montane forest at $1500-2150 \mathrm{~m}$. Most of our fieldwork was carried out in forest-edge habitat (above 1700 m) rather than closed-canopy forest (1500-1700 m).

Site $1 \mathrm{C}$ : Cabanaquinta This site extended from the boundary with humid lower montane forest to a peak at $5^{\circ} 48^{\prime} \mathrm{S} 78^{\circ} \mathrm{O} 1^{\prime} \mathrm{W}$. The terrain was steep, with 
cloud-forest covering slopes of $30^{\circ}-45^{\circ}$. Common plant genera included Ficus, Ocothea, Cecropia and Otoba. Chusquea bamboo was found in more open areas such as tree-fall clearings and land-slides. Forest on the exposed ridgetop at $2550-$ $2650 \mathrm{~m}$ was more stunted, with several dense Chusquea clumps. A narrow track gave access along the relatively flat, 5 to $15-\mathrm{m}$ wide ridgetop. Considerable evidence of pre-hispanic inhabitation included a series of stone walls (some up to $2-\mathrm{m}$ high) and the remains of a circular building on the ridgetop peak at $2650 \mathrm{~m}$. The large extent of these ruins, known locally as Las Ruinas de Cabañaquinta, suggests that they are a valuable archeological site. Much of the forest in this area was intact, probably because of its inaccessibility. There was some evidence of small-scale selective logging below $2300 \mathrm{~m}$ in this zone, but Cedrella montana, the favoured timber, probably does not occur above this altitude. The forest was frequently enshrouded in mist and cloud and appeared very humid, although we did not find running water above $1850 \mathrm{~m}$. We carried out fieldwork in very humid lower montane forest at $2150 \mathrm{~m}$ to the peak at $2650 \mathrm{~m}$.

Site 2A: San Cristobal San Cristobal is a larger village of approximately 500 people located at $5^{\circ} 49^{\prime} \mathrm{S} 78^{\circ} 08^{\prime} \mathrm{W}$ at $1100 \mathrm{~m}$. It is reached from the rio Utcubamba at Puerto del Salao, $5^{\circ} 50^{\prime} \mathrm{S} 78^{\circ} 13^{\prime} \mathrm{W}$, at $550 \mathrm{~m}$. The lower slopes of the mountain range between Puerto del Salao and San Cristobal possess a well-developed irrigation system, and almost all of the forest here has been cleared for cultivation of fruit, rice, coffee and sugar cane, and for livestock grazing. A few small patches of forest do still remain along the río Cristobal. Cultivation gives way to artificial fire-maintained grassland (pajonal) at about $1300 \mathrm{~m}$, extending up to about $1800 \mathrm{~m}$. The grassland areas are frequently burned for pasture, particularly in the dry season (austral winter).

Our observations at this site were concentrated in the cultivated area around the village of San Cristobal, at 900-1100 $\mathrm{m}$ in the humid premontane zone.

Site 2 : Europa cloud-forest Europa is a log cabin in humid lower montane forest, at $5^{\circ} 48^{\prime} \mathrm{S} 78^{\circ} 06^{\prime} \mathrm{W}$, at $1700 \mathrm{~m}$ altitude. An area of approximately 5 hectares has been cleared around the house for cultivation and livestock grazing. Villagers cleared at least another hectare of forest with axes during our two-week stay. The cloud-forest in this area had been heavily degraded, resulting in a mosaic of habitats including secondary shrubbery containing Heliconius and Philodendron, grassy clearings, patches dominated by a white-barked tree with the local name of "balsa", and areas of relatively intact palm-dominated cloud-forest. We carried out fieldwork at $1650-1850 \mathrm{~m}$ in cloud-forest, forest edge and streamside forest.

Site $2 C$ : Europa elfin forest Elfin forest was found on two ridgetops within the Europa area, one at $1650-1750 \mathrm{~m}$, extending roughly 1 to $3 \mathrm{~km}$ from the Europa hut, the other at $1850-1950 \mathrm{~m}$, extending roughly $500 \mathrm{~m}$ to $5 \mathrm{~km}$ from the Europa hut. These altitudes are amongst the lowest at which elfin forest is known to occur on the Cordillera de Colán. Both areas of elfin forest graded into a distinctive type of scrub, similar to that described in Fitzpatrick et al. (1979), with stunted, small-leaved, lichen-covered bushes, scattered trees and up to $40 \%$ exposed rock. This habitat contained a high concentration of flowers, 
including orchids (Orchidaceae), melastomes (e.g. Brachyotum), ferns and succulents. Poor sandy soils leached by high rainfall probably contribute to the existence of elfin forest on exposed ridgetops. The scrub is almost certainly created from elfin forest by burning. Most of this burning is probably deliberate to provide pasture for cattle grazing. We carried out fieldwork throughout the elfin forest at $1650-1750 \mathrm{~m}$ and $1850-1950 \mathrm{~m}$, all within the humid lower montane forest zone.

\section{Results}

\section{Threatened bird species}

Peruvian Pigeon Columba oenops Vulnerable (Collar et al. 1994).

Range and habitat. Restricted to riparian forest and adjacent dry deciduous forest at $800-2400 \mathrm{~m}$ in the Marañón Valley area, Cajamarca, Amazonas and San Martín departments (Collar et al. 1992), with recent records in extreme south-east Ecuador (Collar et al. 1994). It is thought to be uncommon throughout its range (Collar et al. 1992).

Project records. Nine Peruvian Pigeon were recorded in only two days of fieldwork, 13 and 14 July 1994, in and around Comboca village at $1250 \mathrm{~m}$ in humid premontane forest. The pigeons were seen singly or in pairs in fruiting trees by a small stream near to the centre of the village. These fruiting trees attracted a number of other frugivores, including Crested Quetzal Pharomachrus antisianus.

Conseruation status. Our records suggest that Peruvian Pigeon may not be seriously threatened on the Cordillera de Colán. Despite its naturally low population levels, our records near a village indicate that it can tolerate some degree of forest degradation. This species is known to feed on coca seeds (Collar et al. 1992), which may be abundant in cultivated areas on the lower slopes of drier parts of the Cordillera de Colán.

Birds seem not to be hunted for their meat on the Cordillera de Colán; locals consider the value of a pigeon to be lower than that of a rifle bullet. It is unclear whether Peruvian Pigeon is hunted in other parts of its range; it is certainly scarce in areas of high human population, such as Bagua Grande (Collar et al. 1992).

On the other hand, the birds we recorded may have been seasonal altitudinal migrants (Collar et al. 1992) and could have different habitat requirements at other times of the year. Our records show only that Peruvian Pigeon is relatively common at $1250 \mathrm{~m}$ on the Cordillera de Colán, when birds may be concentrated because of food abundance. Further work is required to investigate its status on the mountain range.

Military Macaw Ara militaris Vulnerable (Collar et al. 1994).

Range and habitat. Widespread but local, uncommon and nomadic in humid lowland and hill forest from Mexico to Argentina (Collar et al. 1994).

Project records. Groups were seen daily in humid premontane forest near Comboca village on 13-15 July 1994, and near San Cristobal village on 13-14 August 1994. The maximum group size was 25-31 at Comboca and 11-14 at San Cristobal. The macaws roosted in the canopy and emergent trees on a steep 
forested slope overlooking Comboca (site r.A) and on a cliffside by the río Cristobal near to San Cristobal (site 2A). A small flock of this species was recorded at $3000 \mathrm{~m}$ on the Cordillera de Colán in 1978 (T. S. Schulenberg in litt. 1994).

Conserution status. If other areas of the Cordillera de Colán have similar numbers of Military Macaw, then the mountain range may have a significant population. However, the paucity of Military Macaw records in 1978 in the north-western part of the range (T. S. Schulenberg in litt. 1994) suggests the species may be less common there than in the south-east.

These high macaw numbers relatively near to villages suggest that it is not seriously threatened by hunting or capture for the pet trade in this region; the lower population at San Cristobal may reflect the smaller amount of remaining forest in this area. Hence, loss of habitat now seems a greater threat on the Cordillera de Colán than commercial trade. The apparent lack of threat to macaws from trapping is noteworthy, and may be the result of the area's relative wealth from cash-cropping.

The possibility of a high population of Military Macaw makes the Cordillera de Colán an important area for the conservation of this species. We found no evidence that parrot species are hunted or trapped in the area, indicating its high potential for the conservation of ten parrot species we recorded (C. W. N. Davies, R. Barnes, S.H.M. Butchart, N. Fernandez and N. Seddon, unpublished report 1994).

Royal Sunangel Heliangelus regalis Vulnerable (Collar et al. 1994).

Range and habitat. Previously known only from two widely spaced localities in northern Peru. Fitzpatrick et al. (1977) discovered the species at an altitude of 1800-2200 $\mathrm{m}$ to the north of the Marañon low, on the Cordillera del Condor, east of the rio Chinchipe in Cajamarca department. It is also known at $1450 \mathrm{~m}$, $200 \mathrm{~km}$ east-south-east of the Cordillera de Colán, $15 \mathrm{~km}$ north-east of Jirillo in San Martín department (Davis 1986). At both sites, Royal Sunangel inhabits forest-edge shrubbery on very poor soils (Collar et al. 1992).

Project records. Seen commonly throughout humid lower montane elfin scrub at Europa (site $2 \mathrm{C}$ ), at $1650-1750 \mathrm{~m}$ and $1850-1950 \mathrm{~m}$, with 86 records, almost certainly of fewer than 15 birds, from 16-31 August 1994. Details are presented elsewhere (Seddon et al. 1996).

Conseriation status. A single burning of elfin scrub seems to increase the suitability of habitat for this species by increasing the amount of Brachyotum shrub, an important food plant (Seddon et al. 1996). Its response to annual burning is unknown but it will probably decline with the serious soil erosion and more complete denudation that is likely in the future. As one of three known sites for the Royal Sunangel, the San Cristobal area is vital for its conservation.

\section{Near-threatened bird species}

Black-and-chestnut Eagle Oronetus isidori. This species has a fairly large range in cloud-forest from Venezuela to Argentina (Fjeldså and Krabbe 1990). Our 10 records, at 1500-2300 $\mathrm{m}$ in humid lower montane forest at Tesoro (site $1 \mathrm{~B}$ ) from 18 July to 8 August 1994, are almost certainly of a resident pair in the río Comboca 
valley, as no more than two eagles were seen together, with most records in the same area. Eagles were seen only over large areas of undisturbed forest.

On the Cordillera de Colán, birds do not appear to be hunted for food but raptors are persecuted as a perceived threat to livestock. Black-and-chestnut Eagle prefers less humid west-facing slopes (J. Fjeldså in litt. 1994) where there tends to be higher human population density and correspondingly higher pressure on habitat. Its naturally low population density and dependence on relatively undisturbed habitat puts Black-and-chestmut Eagle under threat.

Black-and-chestnut Eagle seems to be more common in the northernmost parts of its range in Colombia and Venezuela (D. C. Wege pers. comm. 1995). It therefore seems to be under national rather than global threat of extinction.

Long-whiskered Owlet Xenoglaux loweryi Two individuals, probably a pair, were mist-netted on the Cordillera de Colán on 15 October 1978, at c. $2350 \mathrm{~m}$ south-east of La Peca Nueva, by the Louisiana State University project (Cardiff and Remsen 1994). The species is also known at $1890 \mathrm{~m}$ from a ridgetop east of the Cordillera de Colán where the Moyobamba road enters San Martín department (Fjeldså and Krabbe 1990). We did not record it. Although very poorly known, Long-whiskered Owlet seems to be restricted to stunted ridgetop elfin forest where it presumably occurs at low population density.

Ridgetop elfin forest is under critical threat on the Cordillera de Colán and is probably under a similar degree of threat in nearby areas. Long-whiskered Owlet is restricted to a small geographical area and is likely to have declined as a result of habitat fragmentation and degradation. It is probably the bird species under most threat on the Cordillera de Colán. Suitable remaining habitat almost certainly covers fewer than $500 \mathrm{~km}^{2}$. We strongly recommend that its status be changed to Endangered (IUCN codes: A1b, A2b, B1 +2abc, C1, C2a), with Threat codes of 1 (loss or alteration of habitat) and 9 (small range or population), using the system explained in Collar et al. (1994).

As a monospecific genus, the Long-whiskered Owlet makes an important contribution to the fauna of the Cordillera de Colán and of Peru. It is not known to exist within any national park or other effectively protected area; a protected area on the Cordillera de Colán is essential for the conservation of this species.

Grey-breasted Mountain-toucan Andigen hypoglanca Inhabits mossy humid montane forest at 2000-3400 $\mathrm{m}$ from Colombia to southern Peru (Fjeldså and Krabbe 1990). We recorded it 11 times from 22 July to 5 August 1994 at 2300$2650 \mathrm{~m}$ at Cabañaquinta (site $2 \mathrm{C}$ ) in very humid lower montane forest. Although all records were in relatively intact forest at a single site, this was probably our only study area at a sufficiently high altitude for the species.

Russet-mantled Softtail Thripophaga berlepschi Formerly thought to occur only at $2530-3350 \mathrm{~m}$ in Amazonas and La Libertad departments, northern Peru, restricted to ridgetop or timberline elfin forest (Collar et al. 1992), it has recently been discovered in Río Abiseo National Park, further to the south in San Martín department (M. F. pers. obs.). Our six records at Europa (sites $2 \mathrm{~B}$ and $2 \mathrm{C}$ ) in humid lower montane forest, made from 15 to 25 August 1994, were between 1800 and $1950 \mathrm{~m}$, with all but one in elfin forest. Three records were of birds in mixed-species flocks, particularly with Grey-mantled Wren Odontorchilus branicki, in the subcanopy and canopy. The five elfin forest records were all 
within a small area of intact habitat, with burned elfin scrub adjacent. The species has also been recorded on the Cordillera de Colán, south-east of La Peca Nueva, in 1978 (Collar et al. 1992).

Although discovered in low numbers within Río Abiseo National Park, this species is under a high degree of threat. It is rare over most of its range (Collar et al. 1992) and is restricted to a habitat type which is small in extent and which is being rapidly degraded. We recommend its status be upgraded to Vulnerable (IUCN codes: Axb, A2b, B1 +2bc, C1, C2a), with Threat codes 1 (destruction or alteration of habitat) and 9 (small range or population).

Chestnut Antpitta Grallaria blakei Restricted to cloud-forest at $2135-2470 \mathrm{~m}$ in northern and central Peru (Fjeldså and Krabbe 1990). An individual was seen well at $1850 \mathrm{~m}$ on 16 August 1994 in humid lower montane forest below Tesoro (site $1 \mathrm{~B}$ ). As with all Grallaria antpittas, it is shy and almost certainly underrecorded. It is nevertheless familiar to locals in Comboca for its habit of hopping onto paths after mules have passed and may be fairly common in the area. An individual was collected south-east of La Peca Nueva at $247^{\circ} \mathrm{m}$ in 1978 (Graves 1987).

Ochre-fronted Antpitta Grallaricula ochraceifrons With an extremely small range, found only on the Cordillera de Colán (Graves et al. 1983) and nearby areas to the south and east (Ridgely and Tudor 1994) it is known mainly from individuals captured in stunted humid forest at $1850-2000 \mathrm{~m}$. Two individuals were captured on the Cordillera de Colán at 1950-1980 m south-east of La Peca Nueva in 1978 (Graves et al. 1983). Grallaricula antpittas are secretive and difficult to see. Ochre-fronted Antpitta may have been present but overlooked in our study areas.

The low population density and small range of this species make it a high conservation priority. Its range does not extend south to Rio Abiseo and it therefore does not occur in any national park or other effectively protected area. The extreme threat to cloud-forest and elfin forest in the area makes extinction of this species possible in the near future. We therefore recommend its status be changed to Vulnerable, (IUCN codes: $A 1 b, A 2 b, B_{1}+2 C, C_{1}, C_{2} a$ ), Threat codes 1 (loss or alteration of habitat) and 9 (small or fragmented range).

Black-chested Fruiteater Pipreola lubomirskii Rare and local in humid montane forest from southern Colombia to north-eastern Peru (Hilty and Brown 1986). We recorded two at $1750 \mathrm{~m}$ in humid lower montane forest at Tesoro (site 1 ) on 16 July 1994, mist-netted (and photographed) two on 21-22 August 1994 at $1900 \mathrm{~m}$ in humid lower montane elfin forest at Europa (site 2), and recorded two on 26-29 August 1994 at 1800-1900 $\mathrm{m}$ in humid lower montane cloud-forest and elfin forest at Europa (site 2). Our records are the first south of the rio Marañon and suggest sympatry with Masked Fruiteater Pipreola pulchra (unpublished data), currently considered an allospecies (Parker et al. 1982). Black-chested Fruiteater was not recorded outside of relatively intact forest, indicating sensitivity to forest degradation.

Scaled Fruiteater Ampelioides tschudii Inhabits wet forest at $650-2700 \mathrm{~m}$ from western Venezuela to Bolivia (Fjeldså and Krabbe 1990). One female was 
observed at $1700 \mathrm{~m}$ in humid lower montane forest at Tesoro (site 1 ) on 16 July 1994 and another was mist-netted and photographed at $1800 \mathrm{~m}$ in humid lower montane elfin forest at Europa (site 2) on 22 August 1994. This fruiteater was also recorded only in relatively intact forest, indicating sensitivity to forest degradation.

Cinnamon-breasted Tody-tyrant Hemitriccus cinnamomeipectus Known from ridgetop elfin forest from extreme southern Ecuador (Krabbe and Sornoza 1994) to the department of San Martín, Peru (Collar et al. 1992). An individual was collected on the Cordillera de Colán in 1978 (Fitzpatrick and $\mathrm{O}^{\prime}$ Neill 1979), although we recorded none. It must be rare on the Cordillera de Colán, although larger populations may exist on nearby mountain ranges such as the Cordillera del Condor (Collar et al. 1992). It is quite possible that Cinnamon-breasted Todytyrant does not inhabit the southern part of the Cordillera de Colán, through exclusion by Black-throated Tody-tyrant H. granadensis, which is thought to exclude $H$. cinnamomeipectus in other areas (Collar et al. 1992). We recorded a single Black-throated Tody-tyrant on 31 July 1994 at $2500 \mathrm{~m}$ at Cabañaquinta (site 1 ). On the other hand, both $H$. granadensis and $H$. cinnamomeipectus were recorded at a single site near La Peca Nueva in 1978 (T. S. Schulenberg in litt. 1994), suggesting coexistence.

Its small range, lack of protection in any reserve, and specialised habitat suggest that it should be reclassified as Vulnerable, (IUCN codes: Aib, A2b, $\left.\mathrm{B}_{1}+2 \mathrm{bc}_{1}, \mathrm{C}_{1}, \mathrm{C}_{2} \mathrm{a}\right)$, Threat codes 1 (loss or alteration of habitat) and 9 (small range or population). On the other hand, its habitat is probably less threatened on the Cordillera del Condor than on the Cordillera de Colán (J. Fjeldså in litt. 1995).

Bar-winged Wood-wren Henicorhina leucoptera Restricted to stunted forest at $1350-2450 \mathrm{~m}$ in northern Peru (Stattersfield et al. 1995), it has been found both to the north of the río Marañon on the Cordillera del Condor, and to the south in Río Abiseo National Park (Fjeldså and Krabbe 1990), but has never been recorded on the Cordillera de Colán itself. We did not record it, despite coverage of areas of stunted elfin forest within its known altitudinal range. It was also not recorded on the Cordillera de Colán in 1978 (T. S. Schulenberg in litt. 1994). Its congener, Grey-breasted Wood-wren H. leucophrys, was common and easy to observe at both our study sites, so H. leucoptera is unlikely to exist on the Cordillera de Colán. Fitzpatrick et al. (1977) believe that the present range of Bar-winged Wood-wren is largely defined by competition with Grey-breasted Wood-wren and consists of pockets from a previously larger range; this could explain the presence of this species to the south and north of the Cordillera de Colán but not on the range itself.

\section{Other species of conseriation interest}

A further eight species with restricted ranges (Stattersfield ot al 1995.) were recorded and are included in Appendix I. Of these, Red-billed Tyrannulet Zimmerius cinereicapillus has not been recorded previously on the Cordillera de Colán or in nearby areas of the Marañón and Utcubamba valleys. Two species, 
Rusty-tinged Antpitta Grallaria przewalskii and Pale-billed Antpitta Grallaria carrikeri, were not recorded outside of intact forest. This suggests sensitivity to deforestation in the case of G. przerualskii, which we recorded 261 times at Tesoro and Cabañaquinta (site 1) at 1700-2600 $\mathrm{m}$ but which we did not record in the more heavily deforested San Cristobal area (site 2).

\section{Discussion}

In 1994, we found large-scale deforestation on the Cordillera de Colán. This was in stark contrast to fieldworkers in 1978 who found "extensive areas of treeline forest and páramo vegetation ... still pristine" (T. S. Schulenberg in litt. to Collar et al. 1992). The extent of deforestation in the Andes of Peru seems to have been largely unnoticed by Western conservation groups. Even more important is the frightening rate of deforestation; villagers from Comboca and San Cristobal predicted that the Cordillera de Colán would be completely deforested within to years.

The Cordillera de Colán is one of the most important centres of endemism in Peru, inhabited by species peculiar to several faunal zones. We recorded bird species confined to each of five EBAs. Four bird species seem restricted to elfin forest, a habitat under extreme threat, and three of these, Long-whiskered Owlet, Ochre-fronted Antpitta, and Cinnamon-breasted Tody-tyrant are not present in any protected area. These species are likely to become extinct in the near future if the speed of habitat destruction is similar over the rest of their ranges to that on the Cordillera de Colán. The biological importance and high rate of habitat loss make the Cordillera de Colán a high conservation priority. This is recognized by the Peruvian Instituto Nacional de Recursos Naturales (INRENA) which listed the Cordillera de Colán as a priority area for conservation in 1995 (INRENA 1995).

The Asociación Peruana para la Conservación de la Naturaleza (APECO) has offered to collaborate with international conservation organizations in an effort to protect the area but lacks the funds for the prerequisite mapping of land use, either on the ground or by LANDSAT, to define the borders of forest and therefore of a possible protected area. They suggest a three-tier "biosphere" reserve, with traditional agriculture in the outermost section, land-use management in the second tier and an area of totally protected forest on the third tier in the south of the mountain range where the largest area of intact forest remains.

The mayor of Comboca, probably reflecting the views of many on the mountain range, supports the initiation of land-use management projects, believing that they will reduce the pressure on remaining forest and its fauna. He is worried about the imminent exhaustion of biological resources if current trends continue. In particular, he has requested a Cedrella reforestation programme to reduce the over-exploitation of its local population and an intensive pastureimprovement programme to reduce both the amount of land that must be cleared for grazing and the hunting pressure on large mammals in the region. He estimated the cost of such projects in the Comboca area to be U.S.\$200o. If initiated rapidly, effective protection of the Cordillera de Colán is feasible and would be relatively inexpensive. 


\section{Recommendations}

We recommend that Long-whiskered Owlet is reclassified as Endangered and that Ochre-fronted Antpitta, Cinnamon-breasted Tody-tyrant and Russetmantled Softtail are reclassified as Vulnerable.

We strongly recommend the rapid establishment of an effectively protected area on the Cordillera de Colán, which should be centred on the southern part of the mountain range where the largest area of intact forest remains. A conservation initiative could take advantage of the recently improved security situation in the region. Any protected area should contain the following habitats:

1. Elfin forest (very high priority). Elfin forest on the Cordillera de Colán is small in extent and possesses a high degree of faunal endemism. The most exposed elfin forest on ridgetops around the perimeter of the mountain range are probably the most suitable habitat for species such as Long-whiskered Owlet, Royal Sunangel, and Russet-mantled Softtail. This elfin forest is most at threat from burning for pasture and through the use of ridgetop paths.

2. Cloud-forest (high priority). Cloud-forest is threatened by logging for mahogany and clearance for agriculture. It is the most inaccessible habitat but is also that which is most desirable to clear, because the climate is suitable for growing lucrative cash crops, and that which is most vulnerable once cleared. Cloudforest on the Cordillera de Colán is inhabited by a large number of raptors, parrots and other frugivorous birds, and rare mammals (Davies et al. 1994, Butchart et al. 1995, in press).

3. Marañón dry forest (moderate priority). The dry forest of the Marañon valley extends to the lower elevations of the Cordillera de Colán. Most has been heavily degraded, probably because it is easy to penetrate. It supports a fauna with a high degree of endemism, although some of these endemic species, in common with many dry forest birds, seem to tolerate a fairly high level of forest degradation. Threatened bird species such as Peruvian Pigeon would be protected in a reserve created on the Cordillera de Colán if it included this habitat.

Any conservation initiative on the Cordillera de Colán would benefit from the presence of several attractive and unusual birds and mammals in the area, suitable as flagship species. These include: Military Macaw, Long-whiskered Owlet, Royal Sunangel, Yellow-tailed Woolly Monkey Lagothrix flaricauda, Spectacled Bear Tremarctos ornatus. Carnivores such as Puma Felis concolor and Blackand-chestnut Eagle are less suitable for use in the area because they are perceived as pests.

\section{Acknowledgements}

Many thanks to those who helped and supported the project. In particular we would like to thank the late Gerald Durrell, our patron; Rob Clay for his help in researching and planning the project; staff of the Asociación Peruana para la Conservación de la Naturaleza (APECO), especially Dr Mariella Leo, for their 
help with logistics, equipment, and with the writing and translation our report; BirdLife International, especially Adrian Long, Mike Poulsen, David Wege and Beatriz Torres, for their help in formulating this project, and Andrew Rayner for drawing the map for this paper; and Sophie Davies, for helping out with tedious errands in London.

Thanks to other project advisors: Mike Brooke, Tom Brooks, Nigel Collar, Kerry Curran, Jon Fjeldså, Dave Gandy, Katherine Gotto, Graeme Green, Niels Krabbe, Tony Luscombe, Roberto Phillips, Enrique Ortiz, Thomas Schulenberg, Chris Sharpe, Joe Tobias, Kenneth Young, and Susan and Jeremy Zuppinger.

Finally thanks to those who helped us at our study sites: Teofilo and Lidia Le Torre Lopez of Europa, Emiliano Lopez, mayor of Comboca; the brave men of the Ronda Campesina de San Cristobal; and, most importantly, Laynes and Libbi Le Torre Lopez, and Daniel Le Torre Lopez, our indefatigable guide, without whom fieldwork would not have been possible.

\section{Appendix I. Project records of birds of conservation interest.}

Project records of species of conservation interest are given. Included are those listed as Threatened (T) or Near-threatened (NT) (Collar et al. 1994), and those with a restricted range (Stattersfield et al, in prep.). Restricted-range species are classified according to their Endemic Bird Area (EBA): B18, Ecuador-Peru East Andes; B22, Marañón Valley; B24, Andean Ridge-top Forests; B25, North-east Peruvian Cordilleras; B29, East Andean foothills of Peru.

+ Indicates that a species was present but not systematically counted at a site; only informal observations were made.

\begin{tabular}{|c|c|c|c|c|c|c|c|c|}
\hline \multirow[t]{2}{*}{ Bird species } & \multirow[t]{2}{*}{ Status } & \multicolumn{7}{|c|}{ Site } \\
\hline & & EBA & $1 \mathrm{~A}$ & 1B & $1 \mathrm{C}$ & $2 \mathrm{~A}$ & $2 \mathrm{~B}$ & $2 \mathrm{C}$ \\
\hline Black-and-chestnut Eagle Oroatus isidori & NT & & & 10 & & & & \\
\hline Peruvian Pigeon Columbr oenops & $\mathrm{T}$ & $\mathrm{B}_{22}$ & 9 & & & & & \\
\hline Military Macaw Ara militaris & $\mathrm{T}$ & & 33 & & & 14 & & \\
\hline $\begin{array}{l}\text { Spot-throated Hummingbird Leucippus } \\
\text { taczanuicskii }\end{array}$ & & $\mathrm{B}_{22}$ & & 3 & & + & 19 & 2 \\
\hline Rainbow Starfrontlet Coeligena iris & & $B_{18}$ & & & & & 8 & \\
\hline Royal Sunangel Heliangelus regalis & $\mathrm{T}$ & $\mathrm{B}_{24}$ & & & & & & 86 \\
\hline $\begin{array}{l}\text { Grey-breasted Mountain-toucan Andigena } \\
\text { hypoglanca }\end{array}$ & NT & & & & 11 & & & \\
\hline Russet-mantled Softtail Thripophaga berlepschi & NT & B25 & & & & & 1 & 5 \\
\hline Chestnut Antpitta Grallaria blakei & NT & $\mathrm{B} 25$ & & 1 & & & & \\
\hline Rusty-tinged Antpitta Grallaria przeunalskii & & $\mathrm{B} 25$ & & 10 & 251 & & & \\
\hline Pale-billed Antpitta Grallarin carrikeri & & $\mathrm{B} 25$ & & & & & & \\
\hline Black-chested Fruiteater Pipreola lubomirskii & NT & & & 2 & & & 1 & 3 \\
\hline Scaled Fruiteater Ampelioides tschudii & NT & & & 1 & & & & 1 \\
\hline Red-billed Tyrannulet Zimmerius cinereicapillus & & B29 & & & & & & 1 \\
\hline Inca Flycatcher Leptopogon taczanourskii & & B25 & & & 21 & & 4 & \\
\hline Maranón Thrush Turdus maranonicus & & B22 & & & & & & \\
\hline Buff-bellied Tanager Thlypopsis inornata & & $\mathrm{B}_{22}$ & + & & & + & I & \\
\hline
\end{tabular}




\section{References}

Butchart, S. H. M., Barnes, R., Davies, C. W. N., Fernández, M. and Seddon, N. (1995) Threatened manmals of the Cordillera de Colán, Peru. Oryx 29: 275--281.

Butchart, S. H. M., Barnes, R., Davies, C. W. N., Fernández, M., and Seddon, N. (in press) Observations of two threatened primates in the Peruvian Andes. Primate Conseriation 16.

Cardiff, S. W. and Remsen, J. V. Jr (1994) Type specimens in the museum of natural science, Louisiana State University. Occasional Papers of the Musetum of Natural Scionce, Louisina State University 68: 5 .

Collar, N. J., Gonzaga, L. P., Krabbe, N., Madrono-Nieto, A., Naranjo, L. G., Parker, T. A. III and Wege, D. C. (1992) Threatened birds of the Americas: the ICBP/lUCN Red Data Book. Cambridge, U.K.: International Council for Bird Preservation.

Collar, N. J., Crosby, M. J. and Stattersfield, A. J. (1994) Birds to wentch 2-the world list of threatened birds. Cambridge, UK: BirdLife International (BirdLife Cons. Ser. 4).

Davis, T. J. (1986) Distribution and natural history of some birds from the Departments of San Martín and Amazonas, northern Peru. Condor 88: 50-56.

Fitzpatrick, J. W. and O'Neill, J. P. (1979) A new tody-tyrant from northern Peru. Alik 96: $443-447$.

Fitzpatrick, J. W., Terborgh, J. W. and Willard, D. E. (1977) A new species of wood-wren from Peru. Auk 94: 195-201.

Fitzpatrick, J. W., Willard, D. E. and Terborgh, J. W. (1979) A new species of hummingbird from Peru. Wilson Bull. 91: 177-366.

Fjeldså, J. (1992) Biogeographic patterns and evolution of the avifauna of relict high-altitude woodlands of the Andes. Steenstrupia 18: 9-62.

Fjeldså, J. and Krabbe, N. (1990) Birds of the High Andes. Copenhagen: University of Copenhagen.

Graves, G. R. (1987) A cryptic new species of antpitta (Formicariidae: Grallaria) from the Peruvian Andes. Wilson Bull. 99: 313-321.

Graves, G. R., O'Neill, J. P. and Parker, T. A. (1983) Grallaricula ochraceifrons, a new species of antpitta from northern Peru. Wilson Bull. 95: 1-6.

Hilty, S. L. and Brown, W. L. (1986) A guide to the birds of Colombia. Princeton: Princeton University Press.

Holdridge, L. R., Grenke, W. C., Hatheway, W. H., Linag, T. and Tesi, J. A. Jr. (1971) Forest environments in tropical life zones: a pilot study. Oxford: Pergamon Press.

ICBP (1992) Putting biodiversity on the map: priority areas for global conservation. Cambridge, U.K.: International Council for Bird Preservation.

INRENA (1976) Mapa Ecologico del Pern - Amazonas. Lima, Peru: Instituto Nacional de Recursos Naturales, Ministerio de Agricultura.

]INRENA (1995) Estrategia del Sistema Nacional de Areas Naturales Protegidas del Peru: Plan Director. Lima, Peru: Instituto Nacional de Recursos Naturales, Ministerio de Agricultura.

Krabbe, N. and Sornoza, M. F. (1994) Avifaunistic results of a subtropical camp in the Cordillera del Condor, southeastern Ecuador. Bull. Brit. Orn. Club 114: 55-61.

Mittermeier, R. A., Ruiz, H. de M. and Luscombe, A. (1975) A woolly monkey rediscovered in Peru. Ory, $x$ 15: 41-46.

Parker, T. A., Parker, S. A. and Plenge, M. A. (1982) An annotated checklist of Perwirin birds. Vermillion, South Dakota, U.S.A.: Buteo Books.

Richards, P. W. (1952) The tropical rain forest. Cambridge, U.K.: Cambridge University Press.

Ridgely, R. S. and Tudor, G. (1994) A guide to the birds of South Americn: volume II, the sub-oscine passerines. Oxford: Oxford University Press. 
Seddon, N., Barnes, R., Butchart, S. H. M., Davies, C. W. N. and Fernández, M. (1996) Recent observations and notes on the ecology of the Royal Sunangel Heliangelus regalis. Bull. Brit. Onn. Club 116: 46-49.

Stattersfield, A. J., Crosby, M. J., Long, A. J., and Wege, D. C. (1995) A global directory of Endemic Bird Areas. Cambridge, U.K.: BirdLife International (BirdLife Cons. Ser.).

CHARLES W. N. DAVIES

53. New Dozer Rd., Canterbury, Kent CT1 3DP, U.K.

ROGER BARNES

t1 Claremont Driee, Leeds LS6 4 ED, U.K.

STUART H. M. BUTCHART

Department of Zoology, Downing Street, Cambridge CB2 $3 E J$, U.K.

MIRKO FERNANDEZ

Ai.. Brasil 3963, Magdalena, Lima 17, Peru

NATHALIE SEDDON

Newnham College, Cambridge CB3 gDF 